\title{
Emergência de saúde pública global por pandemia de Covid- 19: desinformação, assimetria de informações e validação discursiva
}

\section{Clóvis Ricardo Montenegro de Lima}

Doutor em Ciência da Informação pela UFRJ. Doutor em Administração pela FGV Graduado em Medicina pela UFSC Pesquisador titular do IBICT.

clovismlima@gmail.com

\section{Nancy Sánchez-Tarragó}

Doutora em Documentação e Informação Científica pela Universidade de Granada. Profa. do Departamento de Ciência da Informação e do Programa de PósGraduação em Gestão da Informação e do Conhecimento da UFRN.

nancita1973@gmail.com

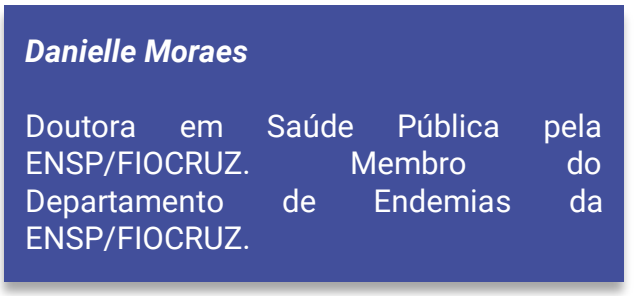

arq.drm@gmail.com

\section{Luciana Grings}

Doutora em Memória Social pela UNIRIO. Coordenadora de Serviços Bibliográficos da FBN, responsável pelas áreas de Depósito Legal, Intercâmbio e Processamento Técnico.

lugrings@gmail.com

\section{Resumo}

Quer-se investigar e discutir os processos e dinâmicas informacionais em torno da emergência global de saúde pública pela pandemia de Covid-19, com ênfase nas manifestações de desinformação ao redor da origem do vírus, da medida de isolamento social e dos tratamentos. Como alicerces teóricos discute os conceitos de desordem informacional, desinformação, assimetria de informações e validação discursiva. A pandemia de Covid-19 atualiza a discussão das estratégias de poder, em um contexto caracterizado pela difusão e uso intenso da informação em tempo real, o uso simples de tecnologias para a edição e publicação de imagens e textos e a emergência do negacionismo científico e a pós-verdade. Esta é uma das grandes novidades desta pandemia, que traz consigo questões críticas de sinceridade, veracidade e honestidade. A sinceridade diz respeito à dimensão subjetiva, a veracidade sobre a dimensão objetiva e a honestidade sobre a dimensão social. Ao mesmo tempo, as notícias na Internet retomam a discussão sobre fraudes que são, de certo modo, uma atualização da questão da "manipulação" nos meios de comunicação. A declaração de alerta sanitário pela Organização Mundial de Saúde dá uma dimensão global para controvérsias sobre objetividade na pandemia. A mudança do modo de comunicação de um para muitos, para uma comunicação de muitos com muitos, torna as questões da informação mais complexas. Na pandemia do Covid-19 são muitas as tensões, controvérsias e conflitos entre autoridades sanitárias, pesquisadores, profissionais de saúde, pensadores críticos e defensores de direitos humanos e sociais. Destaca a importância da validação discursiva da informação pois a disseminação da informação na sociedade enfrenta o filtro do uso público da razão, particularmente aguçado pelo horizonte da finitude humana

Palavras-chave: Covid-19. Pandemia. Assimetria de informações. Desinformação. Validação discursiva.

\section{Global public health emergency due to Covid-19 pandemic: misinformation, information asymmetry and discursive validation}

\section{Abstract}

The aim is to investigate and discuss the informational processes and dynamics surrounding the global public health emergency caused by the Covid-19 pandemic, with an emphasis on the manifestations of disinformation surrounding the origin of the virus, the measure of social isolation and treatments. As theoretical foundations, it discusses the concepts of informational disorder, disinformation, information asymmetry and discursive validation. The Covid-19 pandemic updates the discussion of power strategies, in a context characterized by the diffusion and intense use of information in real time, the simple use of technologies for the editing of images and texts and the emergence of scientific negacionism and post-truth. This is one of the main novelties of this pandemic, which raise critical questions of sincerity, truthfulness and honesty. Sincerity concerns the subjective dimension, truthfulness about the objective dimension 
Mariangela Rebelo Maia

Doutora em Ciência da Informação pelo

IBICT /UFRJ. Professora Substituta no

Departamento de Odontologia Social e

Preventiva na UFRJ.

mariangela.saude@gmail.com

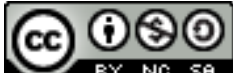

Este trabalho está licenciado com uma

Licença Creative Commons - Atribuição-

NãoComercial-Compartilhalgual 4.0

Internacional. and honesty about the social dimension. At the same time, news on the Internet resumes the discussion about fraud which is, in a way, an update on the issue of "manipulation" in the media. The health warning statement by the World Health Organization gives a global dimension to controversies about objectivity in the pandemic. Changing the way of communicating from one to many, to communicating from many to many, makes information issues more complex. In the Covid-19 pandemic, there are many tensions, controversies and conflicts among health authorities, researchers, health professionals, critical thinkers and human and social rights defenders. Highlights the importance of discursive validation of information as the dissemination of information in society faces the filter of public use of reason, particularly sharpened by the horizon of human finitude

Keywords: Covid-19. Pandemic. Information asymmetry. Disinformation. Discursive validation.

\section{Introdução}

Neste artigo, quer-se investigar os processos e dinâmicas informacionais em torno da emergência global de saúde pública pela pandemia de gripe pelo vírus SARS-CoV-2. A partir disso, quer-se discutir os conceitos de desordem informacional, desinformação, assimetria de informações e validação discursiva.

Em 2018, 51\% da população tinha acesso a Internet ${ }^{1}$, mas com uma penetração muito desigual, sendo muito maior em países do Norte do que em países do Sul, esses com uma história de colonialismo e neocolonialismo, desigualdade e exclusão que se alastra até os dias de hoje. Nesse contexto desigual, existe uma assimetria de informações, pois os atores sociais têm distintas condições e possibilidades de usar, produzir e disseminar informação. Contudo, a proliferação dos telefones celulares, das plataformas de mídias sociais e das tecnologias digitais de edição de textos e imagens, sofisticadas e ao mesmo tempo simples e acessíveis, têm facilitado um volume cada vez maior de mensagens 'poluídas', uma espiral crescente de desinformação que encontra caldo de cultivo na 'era da pós-verdade', do negacionismo científico e da espetacularização da vida.

A desinformação inclui informação errada, memes e sátiras, mas, perigosamente, um acúmulo cada vez maior de notícias e mensagens produzidas, deliberadamente, para enganar, manipular e causar danos por motivos políticos, financeiros e sociopsicológicos (WARDLE; DERAKHSHAN, 2017). A desinformação, uma verdadeira desordem informacional, se expande a velocidades vertiginosas - como um vírus contagioso e mortal.

A finitude do homem tem sido usada historicamente como estratégia de poder. Em uma conferência nos anos 1970, Foucault fez uma importante relação entre a lepra e a soberania; e, entre a peste e a disciplina. Na sociedade de controle, a emergência da AIDS parece ter criado uma outra estratégia de poder, fortemente marcada pelo uso da informação. No final dos anos 1980, com a epidemia de AIDS houve estimativas de mortes catastróficas pela doença. Sangue, sexo e morte se alinharam. Como resultado, em 40 anos houve 30 milhões de mortes no mundo e as drogas antirretrovirais, criadas para combater os efeitos do vírus HIV, se tornaram parte importante do mercado global de medicamentos que fatura 1,3 trilhão de dólares por ano (LIMA, 2005).

A epidemia de Influenza A subtipo H1N1, de 2009-2010, primeiramente nomeada de 'gripe suína', é posteriormente enunciada como a 'primeira pandemia do século XXI'. Comparada à epidemia de gripe espanhola do início do século XX, que foi responsável por milhões de mortes, os processos de mediação e de disputa em torno das informações sobre a epidemia de H1N1 são analisados como fundamentais para considerá-la uma pandemia (GILMAN, 2010). Essas disputas tiveram impacto

\footnotetext{
1 Ver: https://g1.globo.com/economia/tecnologia/noticia/2018/12/07/mais-da-metade-da-populacao-mundial-usa-internet-aponta-onu.ghtml Acesso em: 22 jun. 2020.
} 
importante na dinâmica dos mercados globais, e a produção de pânico moral foi um modo de operação fundamental nesse processo (GILMAN, 2010; LERNER; GRADELLA, 2011).

A pandemia de Covid-19 na China, iniciada no final de 2019, atualiza a discussão das estratégias de poder, agora caracterizadas pelo uso intenso da informação em tempo real, com a Internet. As primeiras notícias sobre a pandemia têm um erro metodológico grave: elas falam de números absolutos e não se referenciam sobre a base populacional. Na China, todos os números são imensos: tem 1,2 bilhão de habitantes e alta densidade demográfica. Lá são diagnosticados todos os anos um milhão de novos casos de tuberculose, uma doença prevenível por vacina ${ }^{2}$. Esse número corresponde a mais de $10 \%$ dos casos globais. Na China também morrem por dia 7.500 pessoas por câncer. Quando a gripe por coronavírus ganhou as manchetes mundiais, no início de 2020, as mortes por Covid-19 eram de menos de 3 mil pessoas.

Em 23 de janeiro de 2020, a Organização Mundial de Saúde (OMS) decretou 'emergência de saúde pública de importância internacional' em virtude da deteç̧ão de casos da Covid-19 em vários países asiáticos, o que indicava a rápida expansão da doença ${ }^{3}$. Contudo, vale destacar que segundo o Centro de Controle e Prevenção de Doenças (CDC) dos Estados Unidos, em 2018, o país teve mais de 40 milhões de casos de gripe, com 900 mil internações e 80 mil mortes numa população de 320 milhões de habitantes. Nada de alerta! Igualmente, no mundo morrem em torno de 60 milhões de pessoas todos os anos. Metade das mortes ocorrem pelas dez principais causas: cardiopatia isquêmica, acidente vascular cerebral (AVC), doença pulmonar obstrutiva crônica, infecções das vias respiratórias inferiores, alzheimer e outras demências, câncer de pulmão, traqueia e brônquios, diabetes mellitus, acidentes de trânsito, doenças diarreicas e tuberculose.

Cabe registrar que, somente após o alerta global, o Brasil começou a se preparar para enfrentar a pandemia por coronavírus iniciada na China. O que não deveria implicar em negligenciar os 180 mil casos de dengue notificados nos dois primeiros meses de 2020 ou a reemergência do sarampo, doença imunoprevenível e com vacina prevista há décadas em calendário nacional de vacinação, em que se espera que $30 \%$ dos casos cursem com complicações, e que tem mobilizado campanhas nacionais de vacinação nos primeiros meses de 2020.

Concordamos com Boaventura de Souza Santos (2020) quando afirma que a primeira lição desta pandemia é que "o tempo político e midiático condiciona o modo como à sociedade contemporânea se apercebe dos riscos que corre" (SANTOS, 2020, p. 22). Ou seja, estamos frente a uma crise grave e aguda, com letalidade significativa e contágio veloz, que rapidamente tem mobilizado a comunidade científica, as mídias e os poderes políticos para resolver suas consequências, mas sem atacar suas causas. Opostamente, crises mais lentas, mesmo com letalidade muito maior, passam despercebidas. De fato, uma questão importante na guerra informacional em que estamos mergulhados é aparecer, apenas de modo marginal, que na base da diminuição da letalidade por Covid-19, dengue ou qualquer doença está o acesso universal e igualitário às ações de vigilância em saúde e à rede de cuidados de saúde básicos e especialidades. Esse acesso vem sendo reduzido de modo sistemático por cortes dos gastos públicos ou concentração da oferta nas mãos de interesses privados.

Por outro lado, a pandemia atualiza a discussão sobre a pseudociência, as controvérsias científicas, as teorias conspiratórias (contribuintes para a desinformação) e suas consequências para a adoção e aderência às medidas de contenção e tratamento da doença por parte de políticos e população, assim como o papel da validação discursiva da informação para enfrentar essa desordem informacional.

Nesse sentido, o artigo utiliza como alicerces para a discussão o marco teórico sobre desordem informacional e desinformação de Wardle e Derakhshan (2017), o conceito de assimetria das informações de Akerlof (1970), de práticas discursivas e poder de Foucault (1992) e de validação discursiva de Habermas (2010).

O artigo está organizado da seguinte forma: depois da introdução, a seção 2 apresenta brevemente a cronologia da emergência global por Covid-19; a seção 3 discute as narrativas concretas de controvérsias e teorias da conspiração

\footnotetext{
2 Ver: Paper de Mello, Silva e Dalcolmo (2018) no Jornal Brasileiro de Pneumologia: https://www.scielo.br/scielo.php?pid=S1806$37132018000200082 \&$ script=sci arttext\&tlng=pt. Acesso em: 22 jun. 2020.

3 Conforme Jamil Chade para a Coluna do Portal UOL. Disponível em: https://noticias.uol.com.br/colunas/jamil-chade/2020/01/30/pormobilizacao-e-recursos-oms-decreta-emergencia-sanitaria-global.htm. Acesso em: 22 jun. 2020.
} 
relacionadas com a origem do vírus SARS-Cov-2, causante da Covid-19, a medida de isolamento social e os tratamentos; a seção 4 apresenta teoricamente os fenômenos de desordem informacional e desinformação; a seção 5 aborda os conceitos de assimetria da informação e validação discursiva da informação, em seu vínculo com a pandemia. $O$ artigo fecha com considerações finais.

\section{A emergência global da OMS pela pandemia de Covid-19}

A OMS, em seu escritório regional na China, foi notificada em 31 de dezembro da ocorrência de casos de uma pneumonia até então desconhecida na cidade de Wuhan. Em quatro dias foram 44 os casos reportados. No dia 7 de janeiro de 2020 o vírus foi identificado pelas autoridades chinesas como uma nova cepa da família dos coronavírus, organismos isolados pela primeira vez em 1937 e descritos na década de 60. Treze dias depois, casos da nova infecção haviam sido reportados em outros três países: Tailândia, Japão e Coreia do Sul. Naquela data, 20 de janeiro, contavam-se 278 casos na China, dos quais seis resultaram em mortes e 51 pacientes estavam em situação crítica (RELATÓRIO..., 2020).

Nesse período inicial, toda a direção da OMS foi acionada e emitiu as primeiras recomendações para redução dos riscos de transmissão e protocolos de pesquisa e tratamento. O primeiro relatório da situação do vírus foi publicado em 21 de janeiro e, desde então, atualizações diárias são publicadas pela organização em seu sítio na Internet. Em 11 de fevereiro, a doença causada pelo novo coronavírus Sars-Cov-2 foi nomeada como Covid-19.

Menos de dois meses depois, o diretor-geral da OMS, Thedos Ghebreyesus, concede entrevista coletiva na qual nomeia a situação como uma pandemia. Na ocasião, em 11 de março, foram reportados mais de 118 mil casos em 114 países, e havia quase 4.300 mortos. O número de infectados havia aumentado 13 vezes, três vezes mais países tinham cidadãos afetados, e a expectativa era de aumentos mais significativos nas semanas seguintes. Ele salienta, entretanto, que se tratava da primeira pandemia declarada pela ação de um coronavírus e, ao mesmo tempo, era situação que poderia ser controlada com ações efetivas: "Se os países detectarem, testarem, tratarem, isolarem, rastrearem e mobilizarem as pessoas, aqueles com poucos casos podem impedir que esses casos virem conglomerados de casos e esses conglomerados levem a uma transmissão comunitária" (GHEBREYESUS, 2020, documento online).

Em seu discurso, Ghebreyesus (2020) salientou que o desafio para os países é encontrar o equilíbrio entre proteger a saúde, minimizar os impactos sociais e econômicos e respeitar os direitos humanos, e recomendou que as ações fossem pautadas por quatro etapas: primeiramente, preparar-se, comunicando à sociedade sobre os riscos e sobre a devida proteção; em segundo, detectar, proteger e tratar todos os casos e rastrear os contatos; terceiro, reduzir o contágio; por último, aprender e inovar. Duas semanas após o pronunciamento, o número de casos e de mortos havia praticamente quadruplicado. Parte desse avanço agressivo da pandemia se deve à demora dos países em adotar as medidas de controle do contágio, principalmente $\mathrm{o}$ isolamento social, em que as pessoas se mantêm em confinamento e evitam o contato com outras pessoas. Essa medida é fundamental porque o período de incubação do novo coronavírus pode ser bastante longo - até quatorze dias -, e durante esse tempo o indivíduo infectado pode estar assintomático, ou com sintomas muito brandos e, assim, transmitir o vírus sem ter conhecimento de ser portador.

Nos Estados Unidos, o primeiro caso da doença foi confirmado em 22 de janeiro. Naquele momento, a China era o epicentro da crise e a pandemia ainda demoraria um mês e meio para ser declarada. O presidente americano, Donald Trump, declarou que a situação estava sob controle, pois se tratava de 'só uma pessoa que veio da China'. Em três de abril, entretanto, os Estados Unidos se tornaram o novo epicentro da recém declarada pandemia, tendo mais de 245 mil infectados e mais de 6 mil mortos. No período entre o primeiro caso e as mais de 6 mil mortes, Trump deu diversas declarações inconsistentes com a gravidade dos fatos: inicialmente, a situação estava sob controle; depois, o vírus seria controlado com a chegada da primavera e o aumento das temperaturas; ainda em fevereiro, anunciou que uma vacina estava em desenvolvimento. Nenhuma das declarações encontrou respaldo científico ou factual e acabaram por causar confusão e insegurança entre os americanos (GIL, 2020).

Já no Brasil, o primeiro caso foi confirmado em São Paulo, em 26 de fevereiro, mas a pandemia havia exigido ações de repatriação de 34 brasileiros que estavam na China e regressaram ao país quinze dias antes. No dia da declaração da pandemia, 11 de março, o Brasil contava com 52 casos confirmados e 907 suspeitos. A curva da pandemia no Brasil evoluiu 
rapidamente: de acordo com o Observatório Covid-19 BR, o número de mortes em meados de abril dobrava a cada 9 dias e 14 horas (PIERRE, 2020); em 24 de abril, havia 3.365 óbitos no país e mais de 50 mil casos.

A atitude do governo brasileiro no que se refere ao enfrentamento da crise se caracteriza pela negação ou por uma minimização. O presidente da República, Jair Bolsonaro, passou a ser reconhecido internacionalmente como um dos quatro líderes nacionais a rejeitar o consenso científico sobre a gravidade da pandemia. O governador do estado de Nova lorque, Andrew Cuomo, considera a ação brasileira "mau exemplo" (GOVERNADOR..., 2020, documento online). Durante o avanço do coronavírus, o presidente denominou a doença de 'gripezinha', insuflou a população a não deixar de frequentar ambientes públicos e ameaçou governadores e prefeitos caso as medidas de isolamento social adotadas em níveis regionais não fossem abrandadas. Em sua narrativa, a defesa da vida com medidas como o isolamento social afronta a manutenção da saúde econômica do país, e essa deve ser priorizada (SANDY; MILHORANCE, 2020).

Como se nota, nas declarações dos presidentes dos Estados Unidos e Brasil, a pandemia de Covid-19 tem estado acompanhada por outra de controvérsias e desinformação, utilizada com fins políticos e geopolíticos. As assimetrias de informação reforçam a visibilidade e predominância de umas narrativas por sobre outras.

\section{Algumas controvérsias na pandemia: origem da Covid-19, isolamento social e tratamento da doença}

Quando um novo vírus emerge, a investigação sobre sua origem é sumamente importante para prevenir sua disseminação na população, desenvolver vacinas e tratamentos e orientar medidas de saúde pública. $\mathrm{Na}$ medida que os cientistas começaram as investigações para determinar a origem do vírus Sars-CoV-2, causante da Covid-19, começaram a circular também diversos rumores e teorias da conspiração, incentivados por disputas e interesses geopolíticos, nacionalismo, racismo e xenofobia. Cedo, surgiram nos Estados Unidos teorias conspiratórias sobre a criação deliberada do vírus em laboratórios chineses como arma biológica; a informação, alegadamente obtida por fontes de inteligência israelita, foi noticiada por um periódico conservador e reproduzida massivamente em diversos sites e mídias sociais. Outra teoria similar, colocava sua origem nos mesmos laboratórios chineses, mas como resultado de um acidente durante a produção de uma vacina (TAYLOR, 2020).

Ironicamente, foi uma pesquisa científica divulgada em 31 de janeiro como preprint (antes da revisão por pares), que esquentou a polêmica, ao sugerir que o vírus parecia ter trechos do genoma do vírus do HIV. Ante a reação da comunidade científica, que rapidamente denunciou falhas metodológicas graves, o preprint foi retratado dois dias depois. Contudo, diversos sites pegaram a história e concluíram que o vírus tinha sido criado em laboratório (MCDONALD, 2020). O artigo de Jessica McDonald (2020) para o site FactCheck. Org mostra a cadeia de desinformação, onde participaram sites reconhecidamente divulgadores de notícias falsas e informação antivacina como ZeroHedge e Health Impact News, combinando a notícia que trazia a conclusão falsa que vinculava o estudo com a origem de laboratório, com twitters de não especialistas corroborando a teoria. Um reconhecido conspiracionista detrás do site InfoWars também divulgou diversos vídeos no seu programa de shows apoiando essa narrativa.

A propósito deste episódio, López-Cózar e Martin-Martin (2020) destacam que diferentemente da resposta da comunidade científica, que rapidamente reagiu com criticidade ao preprint até a retratação dos autores, periódicos de grande alcance como The Angeles Times, The Guardian, The Scientist, Foreing Affair, Newsweek amplificaram acriticamente os resultados do estudo preliminar, contribuindo a uma onda gigante de desinformação. Apontam os autores que segundo os dados do site Altmetric.com, que mede o engajamento online das pesquisas científicas, o estudo tornou-se o mais compartilhado de todos os tempos nas redes sociais, com mais de 20.000 tuítes e 56 notícias de periódicos.

Uma teoria da conspiração mais bizarra ainda, vincula a origem ou a disseminação do vírus às ondas de rádio $5 G$ de telefonia móvel, apontando para seu papel na supressão do sistema imunológico ou como canal de transmissão. Parecem haver surgido em postagens de Facebook, a finais de janeiro, no mesmo tempo em que apareciam os primeiros casos de Covid-19 nos Estados Unidos. Vídeos replicados em plataformas de Instagram e Youtube também mostravam incêndios em torres de 
5G em diversas cidades do Reino Unido, aparentemente como resposta a 'ameaça' do Coronavírus (LAWRIE, 2020). Por outro lado, diplomatas chineses e meios de imprensa russos têm proposto a teoria de que o vírus chegou à China por via de soldados estadunidenses que participaram nos jogos militares de outubro em Wuham (VIDAL LIY; MARS, 2020). No transfundo, Estados Unidos e China travam uma batalha comercial e tecnológica, onde a tecnologia 5G, que hoje domina China, é um dos núcleos da disputa.

Embora a Organização Mundial da Saúde e grande parte da comunidade científica tenham descartado a possibilidade da origem do vírus em laboratórios de qualquer país e sustentem que sua origem é natural, e talvez nem vinculado diretamente ao mercado de Wuham (WORLD HEALTH ORGANIZATION, 2020), a disseminação destas teorias em websites e mídias sociais tem tido uma grande repercussão na população. As acusações têm sido amplificadas também pelo apoio público de alguns políticos em diferentes países. Uma pesquisa feita pelo Pew Research Center, divulgada em 8 de abril, identificou que quase um terço dos estadunidenses (29\%) acreditava que o vírus tinha sido criado em laboratório; destes, a maioria acreditava que tinha sido criado intencionalmente. Já $43 \%$ disseram que sua origem era natural. $O$ estudo identificou diferenças socioculturais, de faixa etária, ideologia e filiação política. Por exemplo, 1 de cada 10 republicanos conservadores acreditava que o vírus foi criado em laboratório, a proporção maior do que em qualquer grupo ideológico (SCHAEFFER, 2020).

Características culturais da alimentação chinesa também tem sido objeto de desinformação com vídeos, compartilhados de maneira "viral", que supostamente mostram a sopa de morcegos como a fonte de infeç̧ão (quando esse prato realmente não está na culinária chinesa) ou o mercado de Wuhan, com imagens de morcegos, ratos e gatos, prontos para comer. Neste segundo caso, como revela artigo de First Draft, coalizão sem ânimo de lucro que investiga desinformação na Internet, dezenas de youtubers pegaram o vídeo original, criado em 2019 no mercado de Langowan, na ilha indonésia de Sulawesi, e removeram os primeiros segundos onde se mostrava a verdadeira locação, adicionando a etiqueta "Wuhan Market". O título, portanto, conectava diretamente o vídeo à alegada fonte de infecção do vírus (REID, 2020). Eis um exemplo destacado de manipulação maliciosa de conteúdo motivado por desejos de demonizar a China. O sociólogo Boaventura de Souza Santos (2020) refletia sobre as implicações atrás da imagem 'primitiva' da China que insinuavam as notícias sobre a vinculação entre a origem da infeção e as más condições higiénicas nos mercados chineses e os seus estranhos hábitos alimentares: "subliminarmente, o público mundial era alertado para o perigo da China, hoje a segunda economia do mundo, vir a dominar o mundo. Se a China era incapaz de prevenir tamanho dano para a saúde mundial e, além disso, de o superar eficazmente, como confiar na tecnologia do futuro proposta pela China?" (SANTOS, 2020, p. 8).

Assim, a desinformação sobre a origem do vírus alimenta tanto a tensão geopolítica, quanto os sentimentos racistas e xenófobos; esses, por sua vez, como numa espiral, continuam também alimentando tensões geopolíticas. Nos Estados Unidos, cidadãos de procedência asiática têm denunciado assédios e discursos de ódio que relembram os enfrentados por muçulmanos, árabes e cidadãos procedentes do sudeste asiático depois do ataque terrorista às torres gémeas. Mas, a diferença da chamada à tolerância de George Bush, Trump endossa e incita os ataques racistas, nomeando a recente infecção por coronavírus como 'vírus chinês' (TAVERNISE; OPPEL JR, 2020). Adicionalmente, alguns políticos, com retórica nacionalista exacerbada, aproveitaram para culpar a imigrantes e refugiados, levando a novos fechamentos de fronteiras e até a pressão para construir "campos de detenção" fechados para essas pessoas (TRILLING, 2020). Por exemplo, um sítio associado à direita alternativa européia divulgou, sem evidências, que um imigrante que tinha se negado a fazer isolamento era o culpado de introduzir o coronavírus na Itália (REID, 2020).

Os ataques racistas têm incluído o Diretor da OMS, Tedros Adhanom Ghebreyesus, com charges representando-o em posições subservientes ao governo chinês. Os ataques têm partido inclusive de líderes políticos como Trump, que o culpa pela demora na resposta à pandemia, e de Bolsonaro. Este último, por exemplo, recentemente justificou sua não aderência às recomendações da OMS ao fato de que Tedros não era nem médico, desdenhando assim o currículo e expertise do Diretor da OMS (OLIVEIRA, 2020). Beaumont, Borger e Boffey (2020) apontam que segundo estudo feito por First Draft, na semana que começa 14 de abril tinham sido publicados 15.000 tuítes usando as hashtags \#tedrosresign e \#tedrosliedpeopledied. Uma parte importante das contas que atacaram o Diretor da Organização Mundial da Saúde eram de apoiadores de Trump. Também, profissionais de saúde, em diversas partes do mundo, têm sofrido discriminação e até violências físicas como consequência da desinformação e o medo ao contágio. Jolley e Lamberty (2017 apud QUIAN, 2020, documento online), aponta que "os pesquisadores têm demonstrado que as teorias da conspiração relacionadas com emergências médicas têm 
o poder de incrementar a desconfiança nas autoridades sanitárias". O mesmo pode ser dito dos ataques pessoais às autoridades de saúde e ao pessoal sanitário. A desconfiança tem consequências graves na aderência da população às medidas de proteção e na adoção de atitudes racionais.

As doenças estão associadas à finitude do corpo humano, particularmente aquelas com maior potencial de matar. As epidemias carregam consigo a carga simbólica do contágio, em que uma pessoa doente transmite a outra a sua afecção. Foucault (2008) observou que os distintos diagramas de poder têm seus próprios modos de enfrentar o contágio. A soberania excluía os indivíduos com lepra; a disciplina esquadrinhava os indivíduos com peste (FOUCAULT, 2008). As sociedades contemporâneas desenvolveram estratégias de controle que combinam elementos dos dois modos anteriores, ao mesmo tempo em que exercem poder médico sobre o real a partir do perigo virtual. A epidemia de AIDS, nos anos 1980, traz este modo de controle de doenças. Isto implicou em enorme discriminação de homossexuais, hemofílicos e usuários de drogas injetáveis, denominando-os como "os perigosos". A falta de vacinas para prevenir e de medicamentos específicos para enfrentar a virose letal, faz que com que a informação se transforme em uma arma (LIMA, 1993, 2005).

A pandemia de Covid-19 traz à tona algumas das mesmas questões médicas, epidemiológicas e de razão prática vividas na epidemia de AIDS. As mesmas discussões de teorias conspiratórias sobre a origem das infecções retornam, assim como a hipótese de contágio de animais para o homem. Também, a controvérsia sobre as medidas contenção (quarentena, isolamento, distanciamento físico) e os limites da vigilância à vida privada dos cidadãos.

Para uma doença como Covid-19 que hoje não tem nem vacina nem tratamento específico, o fechamento de escolas, universidades e comércios, a proibição de reuniões com aglomeração de pessoas, o auto isolamento social (ou distanciamento físico, termo preferido pela OMS), incluindo em alguns países, quarentenas e bloqueios totais, têm sido consideradas como as melhores estratégias para evitar a disseminação descontrolada da infeção e o colapso dos sistemas de saúde, já debilitados na maior parte do mundo por anos de políticas neoliberais e receitas de 'austeridade'.

Embora as pesquisas científicas ainda não sejam conclusivas sobre a eficiência destas medidas, pelas dificuldades de isolar os diversos fatores envolvidos na transmissão; as experiências da China que controlaram sua epidemia depois de um bloqueio total da cidade epicentro do surto, as análises de simulações e alguns estudos empíricos em países onde estas estratégias foram implementadas, apontam para seu benefício em combinação com outras medidas de higiene pessoal (FLAXMAN et. al., 2020; MILNE; XIE, 2020). O ideal seria um mínimo de 50\% do distanciamento nas cidades, até atingir $70 \%$ de isolamento - procedimento realizado nos países que conseguiram controlar a pandemia (REIS et. al., 2020).

Contudo, estas estratégias não têm sido aceitas de forma unânime e diversas controvérsias têm se alastrado nos últimos três meses trazendo incertezas e desorientação à população, encabeçadas, sobretudo, por políticos de direita e empresários que reclamam da crise econômica agravada pela paralisação e fechamento dos comércios, indústrias e outras atividades econômicas.

O caso da Itália é exemplar pois, para não 'gerar o caos' e não desestimular o turismo e o investimento estrangeiro, as mais altas autoridades do governo italiano minimizaram a pandemia, criticaram as medidas tomadas em outros países por 'alarmistas' e chegaram a derrubar na Justiça as medidas de isolamento tomadas por alguns governos locais. Em Milão, a principal cidade da região Lombardia, uma associação de bares e restaurantes criou uma campanha instando a cidadãos a não ter medo e não parar suas atividades. O vídeo tornou-se viral, compartilhado e endossado pelo prefeito da cidade de Milão, Giuseppe Sala. As consequências da política de desestimular o isolamento social foram desastrosas. Em menos de um mês a Itália, e sobretudo a Lombardia, tornavam-se o epicentro mundial da pandemia com mais de 7000 mortos até o dia 25 de março (ALESSI, 2020).

Também, no caso do Brasil, além de minimizar a seriedade da pandemia, Bolsonaro contribui para a disseminação de informações fraudulentas e sem respaldo científico. Ele busca protagonizar a defesa da 'flexibilização' do isolamento social, apesar de estudos científicos dizerem o contrário. Certamente, como tem ocorrido também com a cloroquina como tratamento, as medidas de isolamento social têm sido politizadas, usadas de bandeira para ganhos políticos. 
As primeiras ondas de desinformação vinculadas à pandemia, talvez na sua vertente de dano não intencional, vieram com a proliferação de remédios e tratamentos domésticos para a doença, que se compartilhavam por meio de WhatsApp em grupos familiares e amigos. Muitas pessoas passavam aos seus contatos e disseminavam por meio de outras plataformas de mídias sociais, de boa-fé, acreditando ajudar a outros. Tomar bebidas cítricas, bebidas quentes, banhos quentes, gargarejos de água morna, entre muitos outros remédios e tratamentos pseudocientíficos, se compartilharam mundialmente, as vezes mudando só o nome do médico que aconselhava e a língua na qual se reproduzia a mensagem. Visando enfrentar a situação, a OMS criou uma seção na sua página web para desmentir os principais boatos que circulavam. Contudo, segundo artigo do jornal britânico The Guardian, uma pesquisa da União Europeia, monitorando casos de desinformação, identificou que um terço dos cidadãos do Reino Unido acreditava que a vodca podia ser usada para a higienização das mãos (BEAUMONT; BORGER; BOFFEY, 2020).

Muitos dos conselhos que circulam são inefetivos, mas inofensivos, mas outros têm sido muito perigosos. Finais de março foi reportado que centenas de iranianos tinham morrido e mais de 1000 adoeceram por consumir metanol equivocadamente, depois de rumores de que beber álcool curaria a infecção por Coronavírus (TREW, 2020). Recentemente, o presidente dos EUA, em declaração oficial, afirmou que é possível que haja cura para o coronavírus 'em um minuto' através de injeções de desinfetante e da exposição à luz ultravioleta - que causa câncer de pele (SMITH, 2020), seguido imediatamente por um aumento de chamadas às linhas de emergência.

A busca frenética pela cura montada nas ondas da desinformação e das controvérsias teve seu auge na emergência do rumor de que a cloroquina seria um tratamento efetivo para a doença. O rumor aparentemente tomou força logo que o conhecido empresário Elon Musk divulgou em Twitter um documento que apontava a efetividade da droga, criado por não especialistas que usava falsamente as credenciais das Universidades de Stanford, da Alabama e da Academia Nacional de Ciências dos Estados Unidos como se elas tivessem participado do estudo (MARTINS, 2020). Seguidamente, um popular show do canal conservador Fox News deu palco para um dos autores do documento, que falou de 100\% de sucesso da cura do Covid-19 por meio da cloroquina. Imediatamente, uma onda de buscas na internet pelos termos 'quinina', 'água tónica' e 'remédio para malária' se disparou (DONOVAN, 2020). O twitter de Musk foi apoiado irresponsavelmente por Trump, que numa coletiva de imprensa, em 19 de março, falou que a Administração Federal de Medicamentos (FDA, siglas em inglês) tinha aprovado o uso da cloroquina ou hidroxicloroquina para o tratamento da Covid-19, o que não era certo.

Poucos dias depois, o presidente Bolsonaro também defendeu a eficácia do uso dos medicamentos cloroquina e hidroxicloroquina no combate ao coronavírus, sem as mínimas evidências científicas apoiando as afirmações. Como consequências imediatas destas ondas de desinformação, começou uma corrida às farmácias em busca de cloroquina e as pessoas começaram a automedicar-se, e algumas pessoas tiveram efeitos adversos, intoxicações e complicações clínicas. Dezenas de estudos são iniciados para testar a eficácia destas drogas, de uso controlado para tratamento de enfermidades como malária, lúpus e artrite reumatoide, mas nenhum conseguiu comprovar se o tratamento realmente funciona fora dos pequenos grupos de teste. Ao contrário, alguns estudos indicam efeitos adversos relevantes.

Muitos outros medicamentos são cogitados para tratamento da Covid-19, inclusive os antirretrovirais, mas, segundo os cientistas, não há como ter certeza em curto prazo de sua efetividade sem o desenvolvimento de estudos rigorosos. Além disto, há uma história de dificuldades para produzir medicamentos eficazes contra viroses. Contudo, a ênfase dada à terapia com cloroquina e hidroxicloroquina está fazendo que sejam deixados de lado ensaios clínicos com outros tratamentos que poderiam ser promissórios por falta de pacientes voluntários (LEDFORD, 2020).

A hidroxicloroquina virou uma arma política nas mãos de políticos, como Trump e Bolsonaro, que têm desdenhado abertamente a importância da doença e que, a contramão das autoridades de saúde e da comunidade científica, rejeitam o isolamento social como medida de proteção por estar travando a economia. Afirmar que dispõem de um tratamento barato para a doença, reforça sua tese da exageração do isolamento social. As controvérsias acerca da eficácia do medicamento e a desinformação ao redor do tema têm levado a plataforma Twitter a tomar medidas excepcionais de remover tuítes de proeminentes políticos defensores da cloroquina para combater o Covid-19. 


\section{Desordem informacional e desinformação: o retrato dos tempos atuais}

Segundo o relatório Internet Trends 2019 (MEEKER, 2019), em 2018, 51\% da população mundial tinham acesso à Internet, contudo a inserção é muito desigual, com as porcentagens mais altas em Norte América (89\%) e as mais baixas em África e Médio Oriente (32\%). Entretanto, os números representam um crescimento de mais do dobro com respeito a 2009. O tempo que passamos conectados online também tem crescido, sobretudo a partir do uso de telefones celulares. As plataformas de mídias sociais têm preponderância nestes comportamentos. Segundo o relatório antes mencionado, no final de 2018, 30\% dos usuários da Internet usavam Facebook, 27\% Youtube e 25\% Whatsapp. Seguem de perto, Wechat, com 23\% dos usuários e Instagram, com 19\%. Nestas plataformas, as imagens têm cada vez mais protagonismo, fazendo valer o ditado de "uma imagem vale mais que mil palavras", o que tem repercussão na maneira em que se comunica a informação e seus apelos emocionais.

Como Wardle e Derakhshan (2017, p. 11) colocam no relatório Information Disorder: toward an interdisciplinary framework for research and policymaking, a partir do uso cada vez maior das tecnologias da informação em todos os aspectos da vida social, sobretudo das mídias sociais, enormes e complexas mudanças têm ocorrido na forma em que se produz, comunica e distribui a informação. Esse novo ambiente informacional se caracteriza por:

a) Tecnologias de edição e publicação sofisticadas, econômicas e amplamente acessíveis que facilitam a criação e distribuição de conteúdo a qualquer pessoa;

b) O consumo da informação passou de ser um ato privado a ser um ato público por intermediação das mídias sociais;

c) A velocidade da disseminação da informação tem aumentado devido um ciclo acelerado de notícias, potencializado pelos telefones celulares;

d) A informação circula em tempo real entre pessoas com relações de confiança, portanto, qualquer peça de informação tem menos probabilidade de ser contestada.

As mídias sociais potencializam a transformação do modelo de comunicação de um a muitos (onde esse um era usualmente uma 'autoridade', por exemplo, uma instituição de saúde ou um jornal) a um modelo de comunicação de muitos com muitos. Nessa forma de comunicação a 'autoridade' se dilui, pois qualquer um com acesso a essas plataformas pode ser criador e disseminador de conteúdo.

A partir de Habermas (2003) cabe apontar aqui que a disseminação intensiva de informações traz consigo questões críticas de sinceridade, veracidade e honestidade. A sinceridade diz respeito à dimensão subjetiva; a veracidade, à dimensão objetiva, e a honestidade, à dimensão social. Ao mesmo tempo, as notícias na Internet retomam a discussão sobre fraudes que são, de certo modo, a atualização da questão da 'manipulação' nos meios de comunicação.

Wardle e Derakhshan (2017) apontam que a semelhança aparente entre sites de publicações com reconhecido prestígio e sites com menos rigor na curadoria da informação, inclusive produtores deliberados de notícias fraudulentas, unido a avalanche de informação, faz também com que as pessoas sejam cada vez mais dependentes de familiares e amigos para se guiar nesse ecossistema. Muitas vezes, essas pessoas não possuem competências, hábitos nem condições tecnológicas (por exemplo, acesso pleno à Internet fora de aplicativos como WhatsApp) para checar a informação e suas fontes. As pessoas, então, recebem as mensagens e sem se preocupar na checagem de sua veracidade, propagam-nas para outras pessoas. Pode-se considerar que um desinformado é então levado, muitas vezes, a tornar-se um desinformador, mesmo que involuntariamente, mas movido pela propagação da informação de uma forma irracional (VOLKOFF, 2004).

Outras questões de fundo que fazem mais complexa a interação com o contexto informacional estão relacionadas com o chamado 'declínio da verdade', esse enfraquecimento do papel dos fatos e das análises na vida pública relacionado com a adoção de perspectivas relativistas e subjetivas extremas, com a glorificação da opinião acima do conhecimento (incluindo o especializado), das emoções acima dos fatos (KAKUTANI, 2018). A comunicação, então, como diz Carey (1989), torna-se um ritual, um ato performático, onde o ato de leitura não é motivado pela busca da informação, mas em busca da confirmação das próprias crenças e de uma visão de mundo prefixada. 
Wardle e Derakhshan (2017, p. 4) observam que estamos vivendo uma poluição informacional em escala global, uma desordem informacional, onde existe

[...] uma complexa teia de aranha de motivações para criar, disseminar e consumir mensagens 'poluídas', miríade de tipos de conteúdo e técnicas para amplificar esses conteúdos, inumeráveis plataformas hospedando e reproduzindo esse conteúdo e velocidades vertiginosas de comunicação entre pares em relações de confiança.

A situação ganhou tal proporção que, em 2017, a BBC World Service conduziu um estudo em 18 países que mostrou que $79 \%$ das pessoas estavam preocupadas com a distinção entre realidade e falsidade na Internet, sendo os brasileiros os mais preocupados com essa incerteza (92\%) (CELLAN-JONES, 2017).

Os autores evitam utilizar o termo "fake news" para se referir a essas mensagens poluídas e fraudulentas. Embora o termo seja antigo, ele começou a ganhar visibilidade a raiz do escândalo da Cambridge Analytica e seus vínculos com eleições em Nigéria (2015), Estados Unidos (2016), Brasil (2018) e o Brexit em Reino Unido (2016). Nos últimos 15 anos, o termo tem sido usado para representar diferentes fenômenos que incluem notícias satíricas e paródias, notícias fabricadas, manipulação e propaganda. O termo também tem sido apropriado por grupos políticos para desacreditar informações e argumentos produzidos por opositores ou pela imprensa, portanto, sendo mecanismo de poder para desqualificar mensagens críticas. Essa banalização semântica do termo o faz inadequado para análises rigorosas, pelo que os autores preferem utilizar o conceito mais amplo de desordem informacional.

O espectro da desordem informacional é vasto, inclui sátiras e paródias, que embora criadas sem intenção de dano podem virar problemas por má interpretação das mensagens; conteúdos enganosos para ressaltar ou desqualificar um determinado enquadramento ou argumento; conexões falsas, por exemplo, quando manchetes, fotos e elementos não correspondem ao que diz o conteúdo; contextos falsos, quando conteúdo verdadeiro se compartilha com informação contextual falsa; conteúdo impostor, quando fontes genuínas são utilizadas para 'legitimar' informação fraudulenta; conteúdo manipulado, quando conteúdo genuíno ou inventado é manipulado para enganar ou confundir; conteúdo fabricado, quando a totalidade do conteúdo é falsa, criada intencionalmente para enganar e fazer dano (WARDLE, 2017).

Contudo, para uma melhor compreensão desse espectro, Wardle e Derakhshan (2017) propõem um marco conceitual sobre essa desordem informacional que classifica os tipos de desordem em três: mis-information, des-information e mal-information. Os termos mis-information e des-information, em português são englobados pela palavra desinformação. Contudo, eles apontam a dinâmicas diferentes. Mis-information é compartilhar informação falsa ou incorreta por equívoco, sem o intuito de causar dano; opostamente, des-information é o compartilhamento deliberado de informações falsas com o propósito de enganar e causar danos. Há uma distinção na intencionalidade. Mal-information, sem equivalente em português, são informações genuínas, originalmente criadas para permanecer privadas, compartilhadas na esfera pública para causar danos. Aqui se engloba vazamentos, discursos de ódio e assédios.

Seguindo o modelo de Wardle e Derakhshan (2017), na cadeia da informação dessa desordem informacional - que inclui sua criação, produção e distribuição - participam diversos agentes com diferentes motivações. Os agentes podem ser oficiais (serviços de inteligência, partidos políticos, organizações de notícias) e não oficiais, como grupos de cidadãos. O papel das mídias sociais na desordem informacional deve ser visto como parte de um ecossistema, também conformado pela rádio, televisão e jornais, que alimentam mutuamente as correntes de desinformação. Crescentemente, os jornais e a TV amplificam as notícias criadas e compartilhadas nas mídias sociais, da mesma maneira que as notícias da TV e os jornais são reproduzidas nestas.

Estes autores também destacam, que embora o 'boom' da desinformação tenha focado na discussão política, a poluição abrange muitos outros ambientes sociais, incluindo a saúde e a ciência. Vale a pena realçar que em qualquer destes contextos o compartilhamento de textos, imagens, vídeos e memes responde às posições e aos interesses na vida real dos agentes produtores e disseminadores das mensagens. As motivações para criar e compartilhar desinformação são diversas, mas Wardle e Derakhshan (2017) ressaltam quatro categorias de fatores motivacionais: financeiro, lucrar com a desordem da informação através da publicidade já que essas mensagens geralmente atraem muitos cliques; político, desacreditar um 
candidato político em uma eleição ou outras tentativas de influenciar a opinião pública; social, engajar com um determinado grupo online ou offline; e psicológico, busca ou reforço de prestígio.

Adicionalmente, contribuem de alguma forma para a desordem informacional as controvérsias científicas e as chamadas teorias da conspiração. As controvérsias são definidas como "[...] polêmicas entre peritos, que requerem saber especializado; que tem como objeto, pelo menos em parte, conhecimentos científicos ou técnicos incertos, cujos resultados envolvem disputas de interesse nem sempre muito visíveis" (MONTEIRO, 2009, p. 33). Elas são inerentes ao pluralismo democrático e, na esfera pública, muitas vezes colocam em confronto os campos científicos e jornalístico.

Hodiernamente, nas controvérsias científicas cada vez participam mais agentes fora do campo científico, mas com poder político ou simbólico para intervir, muitas vezes acentuando a desordem informacional. Por outro lado, as teorias da conspiração são "[...] um esforço para explicar algum evento ou prática através de referências a mecanismos de pessoas poderosas que tentam esconder seu papel (ao menos até seus objetivos serem alcançados)" (SUNSTEIN; VERMEULE, 2009, p. 205). Algumas terminam comprovando-se verdadeiras, mas são aquelas falsas, injustificáveis (desde um ponto de vista epistemológico) e prejudiciais as que mais contribuem para a desinformação.

A pandemia de Covid-19 tem sido o novo palco da desordem informacional, com uma mistura indistinguível de informações não verificadas, informações úteis e desinformação, deliberada ou não. Agravam esta situação numerosas controvérsias e teorias conspiratórias relacionadas com a origem do vírus, os possíveis tratamentos e medidas de prevenção e contenção de contágios, reproduzidas e amplificadas pelas mídias. Segundo Larson (2020), entre 1 de janeiro e meados de março de 2020, The Vaccine Confidence Project que monitora mídias sociais detectou mundialmente mais de 240 milhões de mensagens acerca do novo vírus, com uma média de 3.08 milhões de mensagens por dia. A OMS chama a isso de infodemia - um excesso de informação (muitas delas falsas) e rumores, que se alastra rapidamente pelas mídias sociais e outros meios de comunicação e chega a impedir as pessoas o acesso a fontes e informações fiáveis.

A qualidade da informação em saúde tem estado em xeque desde a proliferação dos sites online, o que tem consequências importantes para a veracidade e confiabilidade da informação. Uma meta revisão sistemática recente conduzida por Daraz et. al. (2019), que abrangeu 153 estudos seccionais que avaliaram 11.785 sítios web com informação de saúde orientada a pacientes e públicos geral, concluiu que a informação em saúde online tem uma qualidade subótima, com variações segundo fonte (maior qualidade os sites governamentais) e especialidade (maior qualidade informação sobre medicina interna e anestesiologia). Só os $18 \%$ destes estavam certificados por HONcode, que atesta a aderência do site a princípios básicos de ética da publicação de informação em saúde online.

A infodemia não é um fenômeno novo. Como colocou Sylvie Briand, diretora da divisão de Infectious Hazards Management da OMS: "[...] sabemos que todo surto será acompanhado por uma espécie de tsunami de informações, mas também dentro dessas informações você sempre tem informações erradas, rumores etc. Sabemos que mesmo na Idade Média houve esse fenômeno" (ZAROCOSTAS, 2020, documento online). A diferença é a amplificação deste fenômeno na mesma medida em que cresce a penetração de Internet, as horas que as pessoas passam online e o número de usuários das principais redes e mídias sociais.

\section{Validação discursiva da informação na emergência de saúde pública por Covid-19}

Em um mundo de desigualdade social, econômica, política e tecnológica, o acesso, o uso, a apropriação e a produção de informação são também muito desiguais, muito assimétricos. Em tempos extraordinários como o que vivemos, em que estudos científicos para definir tratamentos e medidas de contenção da Covid-19 ainda não são conclusivos e existe uma mistura gigante de notícias e informações (verdadeiras, erradas e fabricadas), a apropriação de uma conduta única e/ou exclusiva, principalmente para uso de um medicamento ou uma medida como a do isolamento social, está envolvida numa onda de desinformação, desequilibrando relações, podendo levar a tomadas de decisões errôneas pela assimetria de informações.

O conceito de assimetria de informações vem da economia. Essas assimetrias foram inicialmente analisadas por Akerlof (1970), ilustrando esse fenômeno através do mercado de carros usados, num estudo sobre lemon markets. A ideia de que os 
agentes econômicos têm níveis de informações distintos e que a capacidade de obter informações em função dos seus custos também é distinta, está no centro da teoria macroeconômica, como uma das razões das imperfeições do mercado.

Esse conceito tem sido apropriado pelos estudos da informação para se referir a situações e contextos em que os atores sociais têm distintas ações de informação e distintas condições e possibilidades de agir comunicativamente. Essas distinções referem-se às ações de uso e de circulação da informação, mais especialmente às ações de produção da informação. A assimetria de informações supõe que os atores sociais não podem superar a distinção entre eles no quadro do mercado, em função dos custos para todos obterem informações equivalentes. Assim, desenha-se um quadro polifônico nas sociedades desiguais. As múltiplas falas expressam perspectivas distintas, mas também desigualdade. Contudo, pode-se sempre encontrar alguma racionalidade nelas (LIMA, 2006).

Nos dias atuais, o mundo digital enalteceu a 'informação espetacularizada', onde os discursos são construídos e reproduzidos sem o compromisso com a veracidade daquilo que é informado. Com isso, os discursos escondem intenções pragmáticas de domínio, poder, indução, manipulação, entre tantas outras formas de retórica.

Michel Foucault, na década de 1970, afasta-se das práticas discursivas até então propostas e consolida sua obra em contextos práticos não discursivos; em particular, práticas de poder (FOUCAULT, 1992). Considera que o poder não está localizado em uma instituição, e "nem tampouco como algo que se cede, por contratos jurídicos ou políticos. O poder em Foucault reprime, mas também produz efeitos de saber e verdade" (FERREIRINHA; RAITZ, 2010, p. 369).

Em Arqueologia do saber, Foucault (1986, p. 135) dedica boa parte da obra definindo termos como enunciado e discurso, pois "[...] um enunciado tem sempre margens povoadas por outros enunciados". Portanto, considera-se como enunciado um conjunto de signos considerados em seu aparecimento singular e na relação com outros enunciados; a frase como um conjunto de signos considerados por sua adequação às regras da língua e a proposição como um conjunto de signos considerados por valor de verdade. A frase pode conter um ou mais enunciados, mas o enunciado não precisa ser uma frase, ele é uma função da existência. Nesta perspectiva foucaultiana, o discurso é composto por um conjunto de enunciados, na medida em que se apoiem na mesma formação discursiva; ele não forma uma unidade retórica ou formal, indefinidamente repetível e cujo aparecimento ou utilização poderíamos assinalar na história; é constituído de um número limitado de enunciados para os quais podemos definir um conjunto de condições de existência (FOUCAULT, 1986).

Em seu livro Vigiar e punir, Foucault (2008, p. 160) retrata os dispositivos que sustentam a ordem disciplinar: a ordenação espacial, a sanção normalizadora e o exame médico. $O$ autor coloca o exame no centro dos processos que constituem o indivíduo "[...] como efeito e objeto de poder, como efeito e objeto de saber". De acordo com Foucault (2008), as práticas se consolidam a partir de duas esferas: a ciência e os elementos integrantes da cultura. E cada uma dessas esferas têm seus mecanismos de legitimação próprios, atuam como centros de poder e elaboram seu discurso e sua legitimidade. As manifestações de poder se agrupam no plano das relações interpessoais (poder de um indivíduo sobre o outro) e das formas institucionalizadas que operam como espaços fechados (poder de um grupo sobre outro).

A partir do paradigma linguístico, quando se deseja compreender não apenas a questão discursiva, mas essencialmente, a validação dos seus efeitos, a discursividade deve ser incorporada à prática. Sendo assim, em contrapartida à noção de biopoder de Foucault, o discurso como fonte de entendimento baseia-se na Teoria do Agir Comunicativo (TAC), de Jürgen Habermas.

Habermas (2010), em seu ensaio Teorias da verdade, publicado em 1973, diante de algumas teorias da verdade, esboça sua 'teoria discursiva da verdade'. Para Gonçalves e Lima (2014, p. 913-914) "o núcleo da teoria do agir comunicativo de Habermas e da correspondente teoria da verdade pode ser resumido da seguinte forma: usar a linguagem significa, essencialmente, avançar pretensões de validade que devem poder ser justificadas discursivamente".

Mas, Habermas (2010), junto com a Teoria discursiva da verdade, elabora uma pragmática universal que objetiva expor e analisar as condições de possibilidade de comunicação, de seus pressupostos e de suas implicações, inclusive no campo da ética e da política. A pragmática pressupõe uma concepção segundo a qual o significado é relativo a contextos determinados e deve ser considerado a partir do uso dos termos e expressões linguísticos utilizados nesses contextos. O significado não é 
visto como arbitrário, mas como dependente do contexto. E nesse campo, a assimetria informacional interfere diretamente na pretensão de validade do discurso.

Pinzani (2009, p. 80) considera que para Habermas "[...] a verdade é uma pretensão de validade que ligamos a proposições ao afirmá-las". Destacando que as afirmações pertencem aos atos de fala constativos, "[...] elas são a forma tomada por uma proposição e não podem ser nem verdadeiras nem falsas, mas sim legítimas ou ilegítimas". Verdadeira ou falsa é a proposição que se afirma, isto é, o conteúdo da afirmação. Essencialmente, o discurso é uma forma de comunicação caracterizada pela argumentação. Pretensões de validade que se tornaram problemáticas são discutidas para investigar sua legitimidade, para isso, trocam-se argumentos e não informações.

É esse poder de ações sobre as ações, mediadas pela linguagem, que se impõe entre as pessoas estabelecendo um processo discursivo de entendimento que visa a um consenso apoiado em razões ou argumentos. Sendo assim, a ação comunicativa se funda em um "[...] ato hermenêutico de compreensão que pode sempre levar a um questionamento das suas pretensões de validade e, eventualmente, a um discurso no qual tais pretensões devem ser fundamentadas" (PINZANI, 2009, p. 81). A força do melhor argumento não é de natureza lógica, nem empírica, mas motivacional: "um argumento é a fundamentação que deve motivar-nos a reconhecer o valor da validade de uma afirmação, ou de uma ordem, ou de uma avaliação" (PINZANI, 2009, p. 82).

A ampliação dos modos de comunicação de muitos para muitos, como aquelas através da Internet, atualiza e amplia as questões de validação da informação. Não basta a interação discursiva sobre fatos e coisas, é necessário haver a correspondência entre a representação e os acontecimentos. As questões de objetividade das falas na esfera pública são ampliadas no neste modo de comunicação de muitos para muitos. Entre as causas estão a expansão das fontes de informação, e as controvérsias sobre sua autoridade, sinceridade e honestidade. "O ritual pode promover solidariedade social sem implicar que as pessoas compartilham os mesmos valores, ou até mesmo a mesma interpretação do ritual" (KERTZER, 1988, p. 65).

A base do entendimento mútuo eficaz para a coordenação de ação é a aceitação da pretensão de veracidade levantada para declaração de intenção ou solicitação, pretensão autenticada pela racionalidade reconhecível de uma decisão (HABERMAS, 2004). No agir orientado para o entendimento são especificadas as condições para um acordo a ser alcançado na comunicação. Habermas (2003) observa que a ideia fundamental do agir orientado para o entendimento mútuo é a motivação racional de um pelo outro para uma ação de adesão. Isso acontece em virtude do efeito ilocucionário de comprometimento que a oferta de um ato de fala suscita, enquanto que no agir estratégico um atua sobre o outro para ensejar a continuação desejada de uma interação.

A validação parte do entendimento entre sujeitos sobre algo no mundo objetivo. $O$ entendimento intersubjetivo requer deles a expressão dos pontos de vista, com pretensão de sinceridade. As controvérsias demandam esforço de argumentação e aceitação tácita do melhor argumento. As condições desta comunicação ideal entre sujeitos são contrafactuais, mas funcionam como modo de avaliar as condições reais.

Outro ponto que deve ser destacado é que a dinâmica de expressão dos pontos de vista e de argumentação pode e deve ser feita em linguagem natural e simples. Isto é particularmente relevante quando se trata de legitimação de afirmações de cientistas na esfera pública. A questão não é apenas de tradução, mas de sinceridade e de honestidade em relação às normas sociais de dignidade e bem-estar. O que a pandemia do coronavírus tem ensinado é que a exposição intensiva e intensa da finitude dos serem humanos impõe limites para as falas na esfera pública. Assim, as controvérsias ficam dentro das fronteiras da finitude, limitada por uma razão que tem por fundamento último a dignidade humana.

Não basta a autoridade de ser presidente dos EUA para fazer valer uma teoria da conspiração sobre a fabricação do coronavírus 19 em laboratórios na China, quando as evidências apontam para outro sentido. Assim como não basta a autoridade de ser presidente do Brasil para fazer valer a eficácia da cloroquina no tratamento da doença, quando os estudos clínicos apontam para graves efeitos adversos. As pretensões de veracidade das falas de autoridades políticas enfrentam objeção que começa nas parcelas da sociedade que duvidam da sua sinceridade e honestidade. 
Contudo, a resolução da controvérsia torna-se mais complexa quando diz respeito à diferentes ameaças à vida. Isto é particularmente visível na discussão sobre isolamento social, em que a eficácia do distanciamento horizontal para reduzir a disseminação do coronavírus se contrapõe aos óbvios efeitos da medida em termos de recessão econômica e de dificuldade para obter renda. Esta contraposição não é falsa, mas desonesta porque naturaliza um modo de produção historicamente construído.

A recessão econômica esvazia de modo brutal a retórica de equilíbrio fiscal. Por um lado, porque há uma redução geral de preços. Por outro, porque pode ser enfrentada de modo eficaz com o aumento do gasto público. As dificuldades das famílias para obter renda são desiguais na sociedade e requerem uma forte ação redistributiva do Estados com amplos programas de renda mínima e crédito subsidiado para a sobrevivência de pequenas empresas. A controvérsia não é entre vida e economia, mas entre distintas proposições econômicas. De um lado, aquelas amplas parcelas da sociedade que necessitam do Estado para poder se manter em isolamento social horizontal. De outro, aquele $1 \%$ de rentistas e de grandes corporações que fundamentam as suas falas em proposições na busca cega da maximização das suas riquezas e não na defesa da dignidade humana.

\section{Considerações Finais}

A pandemia de gripe por Covid-19 está nos ensinando bastante sobre a relação entre informação científica e política, que está muito além de uma atualização do conflito entre doxa e episteme, entre opinião e verdade.

Em primeiro lugar, houve um intenso conflito para determinar a gravidade da doença viral. O tamanho da epidemia e a letalidade da gripe na China quando apresentado em números absolutos dá uma dimensão assustadora. Apesar disto, a doença foi subestimada por muitos governos com consequências desastrosas. Foi necessário demonstrar a sua capacidade para rápida disseminação e de saturação dos sistemas de saúde para que a Organização Mundial de Saúde declarasse emergência global. Uma das primeiras querelas em torno da epidemia foi a origem do coronavírus, em que não faltaram teorias conspiratórias e xenofobia.

Adicionalmente, foi necessário um grande confronto público entre cientistas e políticos com distintas perspectivas para que a maioria entendesse que o vírus tem características biológicas que indicam fortemente que ele não foi produzido em laboratório. É curioso observar o virologista francês Luc Montaigner entre os defensores de uma hipótese conspiratória.

As doenças transmissíveis podem ser controladas com a proteção específica das vacinas. Contudo, elas demoram para ser desenvolvidas e produzidas com critérios seguros. Assim, especulações sobre iniciativas neste sentido proliferam e há uma guerra pelo pioneirismo. As controvérsias incluem a eficácia de vacinas de uso corrente, com a Sabin contra o sarampo e a BCG contra a tuberculose, com proteção temporária contra o Covid-19.

A rápida disseminação de uma virose que não tem medidas de proteção específica e nem tratamento pode colapsar os sistemas de saúde. Esta é a principal razão para que a Organização Mundial de Saúde recomende medidas de isolamento e de distanciamento social. A aplicação desta medida de proteção para impedir a rápida disseminação do coronavírus tem consequências sociais terríveis. $O$ isolamento social não tem os atributos, modo e expressão em sociedades marcadas pela desigualdade. Os 800 milhões de pessoas no mundo que vivem abaixo da linha da miséria e que passam fome são especialmente vulneráveis.

A paralisia da atividade produtiva traz uma crise econômica sem precedentes na história, com uma correspondente crise do valor do capital e do trabalho. A defesa do isolamento social ou da sua interrupção brusca ou programada se tornam rapidamente uma profunda controvérsia global. Apenas quatros governos nacionais insistem em negar os riscos da pandemia e as vantagens do isolamento social. É importante observar que a resolução desta controvérsia acontece porque os milhões de casos da doença e as centenas de milhares de mortes impõem o isolamento social e reduzem o espaço de contestação. A contraposição entre saúde e economia se reduz a grupos de extrema direita, que se mantêm irredutíveis em negar a ciência e as recomendações das autoridades sanitárias. 
Uma terceira controvérsia relevante acontece em relação aos tratamentos para a doença em suas versões moderada e grave. É um território onde emergem quase diariamente notícias fraudulentas. Neste caso deve-se observar que muitas vezes a origem destas informações está em cientistas ou institutos de pesquisa. Elas são apropriadas e disseminadas de acordo com interesses políticos e econômicos.

Uma das principais controvérsias sobre tratamento da Covid-19 acontece em torno do uso da cloroquina, medicamento disponível para tratamento de malária e de doenças reumatológicas. Há uma longa distância entre a eficácia como antiviral em laboratório e o seu uso corrente autorizado em seres humanos. Atores políticos se apressam a abraçar a ideia do uso da cloroquina, particularmente aqueles interessados no fim do isolamento social. É como se a existência de um medicamento eficaz pudesse liberar a sociedade para interagir livremente. Contudo, logo que são realizadas as primeiras investigações controladas do uso da cloroquina aparecem os seus efeitos colaterais graves.

A cloroquina é abandonada como a panaceia contra a pandemia. A experiência anterior no enfrentamento de viroses mostra ser extremamente difícil desenvolver drogas antirretrovirais. São muitas as razões biológicas para isso, incluindo a mutação genética dos vírus. Emergem outras candidatas a medicamento, seguidas de mais ou menos entusiasmo.

A pandemia de Covid-19 está nos ensinando muita coisa, entre elas que a emergência da morte e da finitude humana no horizonte reduz o espaço para informação fraudulenta e para controvérsias sem correspondência com o mundo objetivo. Uma a uma, as informações não verdadeiras vão naufragando. A disseminação da informação na sociedade enfrenta o filtro do uso público da razão, particularmente aguçado pelo horizonte da finitude humana.

\section{Referências}

AKERLOF, George A. The market for lemons: quality uncertainty and the market mechanism. Quarterly Journal of Economics, [S.I.], v. 84, n. 3, p. 488-500, 1970.

ALESSI, Gil. Itália pagou preço alto ao resistir a medidas de isolamento social para conter Coronavirus. El Pais, São Paulo, 25 mar. 2020. Disponível em: https://brasil.elpais.com/internacional/2020-03-25/italia-pagou-preco-alto-ao-resistir-a-medidas-de-isolamento-social-paraconter-coronavirus.html. Acesso em: 25 abr. 2020.

BEAUMONT, Peter; BORGER, Julian; BOFFEY, Daniel. Malicious forces creating "perfect storm" of coronavirus disinformation. The Guardian, Inglaterra, 24 abr. 2020. Disponível em: https://www.theguardian.com/world/2020/apr/24/coronavirus-sparks-perfect-storm-ofstate-led-disinformation. Acesso em: 25 abr. 2020.

CAREY, James. Communication as Culture: Essays on Media and Society. London: Routledge, 1989.

CELLAN-JONES, Rory. Fake news worries "are growing”. BBC News, Inglaterra, 22 set. 2017. Disponível em: https://www.bbc.com/news/technology-41319683. Acesso em: 22 abr. 2020.

DARAZ, Lubna et al. Can Patients Trust Online Health Information? A Meta-narrative Systematic Review Addressing the Quality of Health Information on the Internet. Journal of General Internal Medicine, [S.I.] v. 34, n. 9, p. 1884-1891, 2019. DOI: 10.1007/s11606-019-051090. Disponível em: https://pubmed.ncbi.nlm.nih.gov/31228051/. Acesso em: 22 abr. 2020.

DONOVAN, Joan. Social-media companies must flatten the curve of misinformation. Nature, Inglaterra, 14 abr. 2020. Disponível em: https://www.nature.com/articles/d41586-020-01107-z. Acesso em: 22 abr. 2020.

FERREIRINHA, Isabella Maria Nunes; RAITZ, Tânia Regina. As relações de poder em Michel Foucault: reflexões teóricas. Revista de Administração Pública. Rio de Janeiro, v. 44, n. 2, p. 367-383, mar./abr., 2010. DOI: https://doi.org/10.1590/S0034-76122010000200008. Disponível em: https://www.scielo.br/pdf/rap/v44n2/08.pdf. A cesso em: 21 jun. 2020.

FLAXMAN, Seth et. al. Report 13 - Estimating the number of infections and the impact of non-pharmaceutical interventions on COVID-19 in 11 European countries. Inglaterra, 30 mar. 2020. Disponível em: http://www.imperial.ac.uk/medicine/departments/schoolpublic-health/infectious-disease-epidemiology/mrc-global-infectious-disease-analysis/Covid-19/report-13-europe-npi-impact/. Acesso em: 29 abr. 2020.

FOUCAULT, Michel. Microfísica do poder. 10. ed. Tradução e organização de Roberto Machado. Rio de Janeiro: Graal, 1992.

FOUCAULT, Michel. A arqueologia do saber. Rio de Janeiro: Forense Universitária, 1986.

FOUCAULT, Michel. Vigiar e punir: nascimento da prisão. Tradução de Raquel Ramalhete. 35. ed., Petrópolis: Vozes, 2008.

GHEBREYESUS, Tedros Adhanom. WHO Director-General's opening remarks at the media briefing on COVID-19-11 March 2020. Genebra: World Health Organization, 11 mar. 2020. Disponível em: https://www.who.int/dg/speeches/detail/who-director-general-s-openingremarks-at-the-media-briefing-on-Covid-19---11-march-2020. Acesso em: 28 mar. 2020.

GIL, Tamara. Coronavírus: como os EUA, com 245 mil casos, se tornaram epicentro da pandemia. BBC News Brasil [S.I.], 3 abr. 2020. Disponível em: https://www.bbc.com/portuguese/internacional-52153503. Acesso em: 22 abr. 2020. 
GILMAN, Sander L. Moral Panic and Pandemics. The Lancet, [S.I.] v. 375, n. 9729, p1866-1867, 2010. DOI: https://doi.org/10.1016/S01406736(10)60862-8. Disponível em: https://www.thelancet.com/journals/lancet/article/PIIS0140673610608628/fulltext?hc location=ufi. Acesso em: 22 abr. 2020.

GONÇALVES, Márcio; LIMA, Clóvis Ricardo Montenegro. Validação discursiva da informação. Linguagem \& Ensino, Pelotas, v.17, n.3, p. 901-925, set./dez., 2014. Disponível em: https://periodicos.ufpel.edu.br/ojs2/index.php/rle/article/view/15319/9507. Acesso em: 22 jun. 2020.

GOVERNADOR de Nova York cita Brasil como mau exemplo de atuação contra COVID-19. CNN Brasil, São Paulo, 22 abr. 2020. Disponível em: https://www.cnnbrasil.com.br/internacional/2020/04/22/governador-de-nova-york-cita-brasil-como-mau-exemplo-de-atuacaocontra-Covid-19. Acesso em: 24 abr. 2020.

HABERMAS, Jürgen. Consciência moral e agir comunicativo. 2 ed. Rio de Janeiro: Edições Tempo Brasileiro, 2003.

HABERMAS, Jürgen. A inclusão do outro: estudos de teoria política. São Paulo: Loyola, 2004.

HABERMAS, Jürgen. Teorias da verdade. In: HABERMAS, Jürgen. Obras escolhidas de Jürgen Habermas: teoria da racionalidade e teoria da linguagem. Lisboa: Edições 70, 2010. v. 2, cap. 5.

KAKUTANI, Michiko. A morte da verdade. Rio de Janeiro: Intrínseca, 2018.

KERTZER, David I. Ritual, Politics, and Power. New Haven: Yale University Press, 1988.

LARSON, Heidi J. Blocking information on COVID-19 can fuel the spread of misinformation. Nature, Inglaterra, v. 580, n. 7803, p. 306-306, 2020. Disponível em: https://www.nature.com/articles/d41586-020-00920-w. Acesso em: 25 abr. 2020.

LAWRIE, Eleanor. 'Absurdo total': cientistas condenam "teoria" espalhada na internet de que 5G transmite coronavírus. BBC News Brasil, [S.I.] 07 abr. 2020. Disponível em: https://www.bbc.com/portuguese/internacional-52194322. Acesso em: 23 abr. 2020.

LEDFORD, Heidi. Chloroquine hype is derailing the search for coronavirus treatments. Nature, Inglaterra, 24 abr. 2020 . Disponível em: https://www.nature.com/articles/d41586-020-01165-3. Acesso em: 25 abr. 2020.

LERNER, Kátia; GRADELLA, Pedro de Andréa. Mídia e pandemia. Os sentidos do medo na cobertura de Influenza H1N1 nos jornais cariocas. Revista Eco-Pós, Rio de Janeiro, v.14, n.2, 2011. (Dossiê Comunicação e Catástrofe) DOI: https://doi.org/10.29146/ecopos.v14i2.1204. Disponível em: https://revistaecopos.eco.ufri.br/eco pos/article/view/1204. Acesso em: 23 abr. 2020.

LIMA, Clóvis Ricardo Montenegro de. AIDS - as epidemias dos vírus e das informações. Ciência da Informação, [S.I.], v. 22, n. 3, dec. 1993. Disponível em: http://revista.ibict.br/ciinf/article/view/477/477. Acesso em: 29 abr. 2020.

LIMA, Clóvis Ricardo Montenegro de. AIDS - uma epidemia de informações. 2. ed. Rio de Janeiro: E-papers, 2005.

LIMA, Clóvis Ricardo Montenegro de. Informação, assimetria de informações e regulação do mercado de saúde suplementar. Encontros Bibli - Revista Eletrônica de Biblioteconomia e Ciência da Informação, Florianópolis, n. esp., 1ํㅗ. sem. 2006. DOI:

https://doi.org/10.5007/1518-2924.2006v11 nesp1p132.Disponível em: https://periodicos.ufsc.br/index.php/eb/article/view/15182924.2006v11nesp1p132. Acesso em: 29 abr. 2020.

LÓPEZ-CÓZAR, Emilio Delgado; MARTíN-MARTíN, Alberto. La viralidad de la ciencia defectuosa: el contagioso impacto mediático de un preprint en bioRxiv sobre el coronavirus y sus efectos en la comunicación científica. Granada, 30 marzo 2020. DOI: 10.13140/RG.2.2.12666.44485. Disponível em: http://hdl.handle.net/10481/60872. Acesso em: 25 abr. 2020.

MARTINS, Carlos. Como a cloroquina virou a salvação da lavoura. Baguete, Porto Alegre, 8 abr. 2020. Disponível em: https://www.baguete.com.br/noticias/08/04/2020/como-a-cloroquina-virou-a-salvacao-da-lavoural. Acesso em: 25 abr. 2020.

McDONALD, Jessica. Baseless Conspiracy Theories Claim New Coronavirus Was Bioengineered. FactCheck.org, [S.I], 7 Feb. 2020. Disponível em: https://www.factcheck.org/2020/02/baseless-conspiracy-theories-claim-new-coronavirus-was-bioengineered/. Acesso em: 23 abr. 2020.

MEEKER, Mary. Internet Trends 2019. [S.I.]: Bondcap, 2019. Disponível em: https://www.bondcap.com/report/itr19/. Acesso em: 23 abr. 2020.

MILNE, George J.; XIE, Simon. The Effectiveness of Social Distancing in Mitigating COVID-19 Spread: a modelling analysis. medRxiv, [S.I.], 23 mar. 2020. DOI: https://doi.org/10.1101/2020.03.20.20040055. Disponível em:

https://www.medrxiv.org/content/10.1101/2020.03.20.20040055v1. Acesso em: 25 abr. 2020.

MONTEIRO, Maria da Graça Mirande de França. Ciência e risco: as controvérsias como procedimento da comunicação pública num contexto democrático. 2009. 393 f. Tese (Doutorado em Comuncação) Programa de Pós-Graduação em Comunicação, Universidade de Brasília, Brasília, 2009. Disponível em: https://repositorio.unb.br/handle/10482/4412. Acesso em: 25 abr. 2020.

OLIVEIRA, Mayara. Bolsonaro desdenha de diretor-geral da OMS: "Não é médico". Metrópoles, Brasília, 23 abr. 2020. Disponível em: https://www.metropoles.com/brasil/politica-brasil/bolsonaro-desdenha-de-diretor-geral-da-oms-nao-e-medico. Acesso em: 25 abr. 2020.

PIERRE, Eduardo. Curva de mortes de Covid-19 no Brasil é mais rápida que a da Espanha, dizem universidades. G1, Rio de Janeiro, 23 abr. 2020. Disponível em: https://g1.globo.com/bemestar/coronavirus/noticia/2020/04/23/curva-de-mortes-de-Covid-19-no-brasil-esta-maisrapida-que-a-da-espanha-dizem-universidades.ghtml. Acesso em: 24 abr. 2020.

PINZANI, Alessandro. Habermas. Porto Alegre: Artmed, 2009.

QUIAN, Alberto. Pandemia de mentiras sobre el coronavirus: así amenaza nuestra salud y la democracia. ctxt, Espanha, 21 abr. 2020. Disponível em: http://ctxt.es/es/20200401/Politica/31843/bulos-redes-fake-news-democracia-pandemia-Covid-conspiranoicos-alberto-quianinfodemia.htm. Acesso em: 23 abr. 2020. 
REID, Alastair. The 6 types of coronavirus misinformation to watch out for. First Draft, [S.I.], 27 mar. 2020. Disponível em: https://firstdraftnews.org:443/latest/the-6-types-of-coronavirus-misinformation-to-watch-out-for/. Acesso em: 25 abr. 2020.

REIS, Ruy Freitas et al. Nota Técnica 02: características e projeções da pandemia Covid-19 no Brasil, em Minas Gerais e Juiz de Fora. Juiz de Fora: Universidade Federal de Juiz de Fora, 2020. Disponível em:

https://www.ufff.br/pgmc/files/2020/03/nt02 covid19 pgmc ufff2.pdf. Acesso em: 24 abr. 2020.

RELATÓRIO de situação da OMS. [Brasília]: [s.n.], 2020. Disponível em: https://saude.gov.br/images/pdf/2020/ianeiro/22/novo-coronavirusresumo-e-traducao-oms-22jan20-nucom.pdf. Acesso em: 21 jun. 2020.

SANDY, Matt; MILHORANCE, Flávia. Brazil's President Still Insists the Coronavirus is Overblow. These Governors are Fighting Back. Time, Estados Unidos da América, 6 abr. 2020. Disponível em: https://time.com/5816243/brazil-jair-bolsonaro-coronavirus-governors/. Acesso em: 22 abr. 2020.

SANTOS, Boaventura de Sousa. A Cruel Pedagogia do Vírus. Coimbra: Almedina, 2020.

SCHAEFFER, Katherine. Nearly three-in-ten Americans believe COVID-19 was made in a lab. Pew Research Center, [S.I.], 08 Apr. 2020 Disponível em: https://www.pewresearch.org/fact-tank/2020/04/08/nearly-three-in-ten-americans-believe-Covid-19-was-made-in-a-lab/. Acesso em: 23 abr. 2020.

SUNSTEIN, Cass R.; VERMEULE, Adrian. Conspiracy Theories: Causes and Cures. Journal of Political Philosophy, [S.I.], v. 17, n. 2, p. 202-227, 13 Apr. 2009. DOI: https://doi.org/10.1111/j.1467-9760.2008.00325.x. Disponível em: https://onlinelibrary.wiley.com/doi/full/10.1111/j.1467-9760.2008.00325.x. Acesso em: 23 abr. 2020.

SMITH, David. Coronavirus: medical experts denounce Trump's theory of 'disinfectant injection'. The Guardian, Estados Unidos da América, 24 Apr. 2020. Disponível em: https://www.theguardian.com/world/2020/apr/23/trump-coronavirus-treatment-disinfectant. Acesso em: 24 abr. 2020.

TAVERNISE, Sabrina; OPPEL JR, Richard A. Spit On, Yelled At, Attacked: Chinese-Americans Fear for Their Safety. The New York Times, Estados Unidos da América, 23 Mar. 2020. Disponível em: https://www.nytimes.com/2020/03/23/us/chinese-coronavirus-racist-attacks.html. Acesso em: 23 abr. 2020.

TAYLOR, Adam. What caused the coronavirus? A skeptical take on the theories about the outbreak's Chinese origin. Washington Post, Estados Unidos da América, 16 Apr. 2020. Disponível em: https://www.washingtonpost.com/world/2020/04/16/what-caused-coronavirusskeptical-take-theories-about-outbreaks-chinese-origin/. Acesso em: 23 abr. 2020.

TREW, Bel. Hundreds dead in Iran from drinking methanol amid fake reports it cures coronavirus. The Independent, Inglaterra, 27 Mar. 2020. Disponível em: https://www.independent.co.uk/news/world/middle-east/iran-coronavirus-methanol-drink-cure-deaths-fakea9429956.html. Acesso em: 23 abr. 2020.

TRILLING, Daniel. Coronavirus offers an excuse to close borders. That would be a mistake. The Guardian, Inglaterra, 26 abr. 2020. Disponível em: https://www.theguardian.com/commentisfree/2020/apr/26/coronavirus-close-borders-pandemic. Acesso em: 29 abr. 2020.

VIDAL LIY, Macarena; MARS, Amanda. La pandemia abre un nuevo campo de batalla entre Estados Unidos y China. EI Pais, Espanha, 21 marzo 2020. Disponível em: https://elpais.com/internacional/2020-03-21/la-pandemia-abre-un-nuevo-campo-de-batalla-entre-estadosunidos-y-china.html. Acesso em: 23 abr. 2020.

VOLKOFF, Vladimir. Pequena história da desinformação: do cavalo de Tróia à Internet. Curitiba: Ed. Vila do Príncipe, 2004.

WARDLE, Claire. Fake news. It's complicated. First Draft, [S.I.], 16 Feb. 2017. Disponível em: https://firstdraftnews.org:443/latest/fakenews-complicated/. Acesso em: 22 abr. 2020.

WARDLE, Claire; DERAKHSHAN, Hossein. Information Disorder: Toward an interdisciplinary framework for research and policymaking. Strasbourg Cedex: Council of Europe, 2017. Disponível em: https://edoc.coe.int/en/media/7495-information-disorder-toward-aninterdisciplinary-framework-for-research-and-policy-making.html. Acesso em: 22 abr. 2020.

WORLD HEALTH ORGANIZATION. Reducing animal-human transmission of emerging pathogens. Genebra: World Health Organization, 26 Mar. 2020. Disponível em: https://www.who.int/health-topics/coronavirus/who-recommendations-to-reduce-risk-oftransmission-of-emerging-pathogens-from-animals-to-humans-in-live-animal-markets. Acesso em: 23 abr. 2020.

ZAROCOSTAS, John. How to fight an infodemic. The Lancet, [S.I.], v. 395, n. 10225, p. 676, 2020. Disponível em: https://www.thelancet.com/pdfs/journals/lancet/PIIS0140-6736(20)30461-X.pdf. Acesso em: 23 abr. 2020.

Artigo submetido em: 05/06/2020. Aceito em: 22/06/2020.

\section{UFCa UNIVERSIDADE}

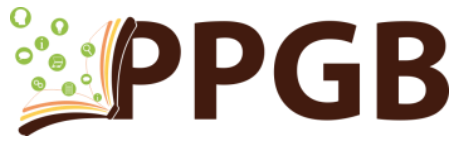

Centro de Ciências Sociais Aplicadas

Mestrado Profissional em Biblioteconomia

Este periódico é uma publicação do Programa de Pós-Graduacão em Biblioteconomia da Universidade Federal do Cariri em formato digital e periodicidade quadrimestral. 